УДК 34

DOI $10.21661 / \mathrm{r}-554348$

Максимова В.И., Махмутова С.А., Жданов С.З., Сакаева Э.3

\title{
ВОПРОСЫ УСЫНОВЛЕНИЯ
}

\section{В МЕЖДУНАРОДНОМ ЧАСТНОМ ПРАВЕ}

Аннотация: в рассматриваемой статье рассматриваются вопросы усыновления с участием иностранного элемента. Рассматриваются нормы международного права, система российского законодательства регулирующее вопросы усыновления детей иностранными гражданами. Особенно подчеркивается, что при этом должны учитываться основные механизмы защитыы прав детей. Также исследуется порядок и механизм усыновления детей иностранными гражданами в Российской Федерачии.

Ключевые слова: международное частное право, семейное право, семья, родители, право, усыновление, удочерение.

Усыновление или удочерение представляет собой юридический акт, в результате которого на воспитание передаются дети несовершеннолетнего возраста, формируются личные и имущественные правоотношения, существующие между родителями и детьми.

Наиболее сложный механизм установления имеет место тогда, когда в данном юридическом акте принимает участие иностранный гражданин. В данном случае установление осуществляется на основании норм международного частного права, а также российского законодательства [2].

Можно обозначить, что институт усыновления с участием иностранного элемента имеет множество проблем, в частности, нарушаются права несовершеннолетних, имелись факты преступной деятельности путем торговли детьми, а также прочие злоупотребления. Помимо этого, достаточно частым случаями бывают такие, когда родители устанавливали ребёнка, увозили его за границу, а в последующем отказывались от усыновленного. В связи с этим, семейное 
законодательство непрерывно совершенствуется, международное сотрудничество в данной сфере также подлежит непрерывному корректированию [3, с. 163]. Институт усыновления регулируется на международном уровне, в частности Европейской конвенцией об усыновлении детей 1967 года. Усыновление иностранными гражданами и усыновление за границей - сложный правовой вопрос, и международное право устанавливает более высокие стандарты и требования для усыновления.

Система усыновления в международном праве закреплена в Конвенции ООН о правах ребенка 1989 года, гарантирующая права и интересы несовершеннолетних в случае усыновления.

Рекомендации Комитета министров ЕС по содействию семьям и Конвенция 1993 года о защите детей и сотрудничестве в отношении иностранного усыновления наиболее полно освещают вопросы осуществления усыновления с участием иностранного элемента.

Важно обозначить, что основные противоречивые вопросы при установлении с участием иностранного элемента разрешаются на основе применения коллизионных норм. В первую очередь необходимо подчеркнуть, что в данном случае применяется личный закон усыновителя несовершеннолетнего лица-гражданина России. Кроме этого, в настоящее время при усыновлении российских детей предусмотрена необходимость строгого соблюдения российского законодательства, регулирующего вопросы усыновления детей, а также строгого соблюдения международных договоров Российской Федерации [4, с. 165].

Когда семья состоит из гражданина Российской Федерации и иностранного гражданина, усыновление российских детей осуществляется на основании норм семейного законодательства Российской Федерации с соблюдением возложенных на Российскую Федерацию международных обязательств.

Законодатель установил применение закона компетентного органа в случае усыновления иностранного гражданина на территории Российской Федерации. Установлен перечень случаев, когда для усыновления требуется согласие 
компетентного органа Российской Федерации, законных представителей ребенка и самого ребенка.

В случае возможного нарушения прав ребенка при усыновлении иностранцами необходимо отказать в усыновлении или отменить усыновление в суде.

Консульские учреждения Российской Федерации обязаны защищать права и интересы детей-граждан Российской Федерации, усыновленных иностранными гражданами за пределами Российской Федерации.

При усыновлении детей, являющихся гражданами Российской Федерации, за пределами Российской Федерации применяется право компетентного учреждения государства, гражданином которого является усыновитель. Для такого усыновления необходимо получить предварительное разрешение компетентного органа Российской Федерации.

Несомненно, иностранное усыновление, как и любая другая форма патронатного воспитания, нуждается в улучшении, включая меры международного и национального контроля. В данном случае целесообразно:

- принятие мер по совершенствованию деятельности органов опеки и попечительства;

- повышение требований к людям и организациям, вовлеченным в процесс усыновления;

- тщательный отбор кандидатов в приемные родители, проведение их психологического тестирования, полная осведомленность кандидатов в приемные родители о здоровье и состоянии усыновленного ребенка;

- строгое соблюдение законодательства РФ при усыновлении детей.

СМИ и правозащитные организации недавно начали отстаивать интересы детей. В связи с этим необходимо усилить информационную кампанию по международному усыновлению. В том числе:

- формирование в СМИ адекватного имиджа приемной семьи иностранных граждан;

- формирование понимающего отношения общества к приемным семьям приемных родителей-иностранцев; 
- требуется создать сайт, посвященный международному усыновлению. Он должен работать на английском, немецком, испанском и итальянском языках (потому что это страны, представители которых чаще всего усыновляют детей из России) [5, с. 332].

Разработка и введение в действие такого интернет-ресурса предоставит возможность иностранным гражданам получить всю необходимую информацию для усыновления ребёнка из Российской Федерации, поможет им собрать всю необходимую документацию, познакомиться с будущим ребёнком и получить о нём всю необходимую информацию. Аналогичный сайт уже функционирует в Санкт-Петербурге. Данная мера поможет решить проблемные вопросы «липового» посредничества.

Часто агентства, которые помогают иностранным гражданам просто обманывают иностранцев. Иностранные граждане сталкиваются с языковым барьером и вынуждены платить таким посредникам большую сумму денег, в то время как вся необходимая информация могла бы быть получена именно на разработанном интернет-сайте, информация предоставляться должна в открытом доступе.

Кроме этого, требуется улучшить подготовку детей-сирот к процедуре международного усыновления.

Необходимо организовать службы поддержки приемных иностранных семей. Как один из возможных проектов: создание в государственном посольстве приемного родителя социальной службы, которая будет курировать адаптацию ребенка в семье. Поручить консульским учреждениям изучить условия жизни детей, усыновленных иностранными гражданами и зарегистрированных на территории консульского округа. Он предусматривает с законодательной точки зрения необходимость правового регулирования порядка исполнения данного обязательства. Параллельно следует предпринять шаги по развитию института прокуроров по надзору за консульскими учреждениями [6, с. 189]. 
Необходимо заключение двусторонних международных соглашений в области усыновления, «которые создадут эффективный механизм контроля за судьбой детей, усыновленных на территории иностранного государства.

Без этих мер развитие института международного усыновления в России будет затруднено.

\section{Список литературь}

1. Конституция Российской Федерации (принята всенародным голосованием 12.12.1993) (ред. от 01.07.2021) // Российская газета. - 1993. - №1213.

2. Бердегулова Л.А. Разграничение сфер международного публичного и частного права / Л.А. Бердегулова, А.Р. Сабитова // Научный электронный журнал [Электронный ресурс]. - Режим доступа: http://e-scio.ru/?p=4475 (дата обращения: 20.06.2021).

3. Бердегулова Л.А. Международное частное право / Л.А. Бердегулова, Э.3. Сакаева // Международный журнал прикладных и фундаментальных исследований. - 2011. - №7. - С. 163-163.

4. Богуславский М.М. Международное частное право / М.М. Богуславский. - М.: Юрайт, 2015. - 654 с.

5. Батычко В.Т. Международное частное право / В.Т. Батычко. - М.: Юрайт, 2016. $-423 \mathrm{c}$.

6. Богуславский М.М. Международное частное право / М.М. Богуславский. - М.: Юристь, 2015. - 419 с.

7. Звеков В.П. Международное частное право: курс лекций / В.П. Звеков. М.: Юрлитинформ, 2016. - 344 с.

Максимова Валентина Ильини - студент, Стерлитамакский филиал ФГБОУ ВО «Башкирский государственный университет», Стерлитамак, Россия.

Махмутова Сабина Альбертовна - студент, Стерлитамакский филиал ФГБОУ ВО «Башкирский государственный университет», Стерлитамак, Россия.

Жданов Сагит Зуфарович - студент, Стерлитамакский филиал ФГБОУ ВО «Башкирский государственный университет», Стерлитамак, Россия. 
Сакаева Эльвира Зинуровна - канд. экон. наук, доцент, Стерлитамакский филиал ФГБОУ ВО «Башкирский государственный университет», Стерлитамак, Россия. 